\title{
Fuzzy Description: Discovery and Invention in Sociology
}

Philip Manning

Cleveland State University, p.manning@csuohio.edu

Follow this and additional works at: https://engagedscholarship.csuohio.edu/clsoc_crim_facpub

Part of the Other Sociology Commons

How does access to this work benefit you? Let us know!

\section{Original Citation}

Manning, P. (1994). Fuzzy description: discovery and invention in sociology. History of the Human Sciences, 7, 1, 117-123.

\section{Repository Citation}

Manning, Philip, "Fuzzy Description: Discovery and Invention in Sociology" (1994). Sociology \& Criminology Faculty Publications. 66.

https://engagedscholarship.csuohio.edu/clsoc_crim_facpub/66

This Article is brought to you for free and open access by the Sociology \& Criminology Department at EngagedScholarship@CSU. It has been accepted for inclusion in Sociology \& Criminology Faculty Publications by an authorized administrator of EngagedScholarship@CSU. For more information, please contact library.es@csuohio.edu. 


\title{
Fuzzy description: discovery and invention in sociology
}

\author{
PHILIP MANNING
}

The term 'social constructionism' is often used but rarely defined. For many sociologists, it has its origins in Berger and Luckmann's classic text, The Social Construction of Reality (1966) in which social constructionism is virtually identical to the sociology of knowledge, the task of which is to analyse everything that passes for 'knowledge' in society (1966: 26). John Kitsuse (1962) used the term to re-characterize the sociology of deviance, changing its focus from the question of why people behave in strange ways to the question of why some people care about how other people behave. More recently, Kenneth Gergen has defined social constructionism as the explication of the 'processes by which people come to describe, explain, or otherwise account for the world (including themselves) in which they live' (1985:266). In this article I define social constructionism very generally as the ways in which a person's understanding and interpretation of an activity are constitutive of the activity itself. From this perspective, to understand an activity is to recover the ways in which practitioners make sense of that activity. When viewed in this way, social constructionism can be seen as a warrant for various strands of interpretative sociology. However, this social constructionist argument is not limited to the subject-matter of sociology but can also be applied to sociology itself. This radical gesture introduces a reflexive component that is not evident in the definition of social constructionism offered by Gergen. It threatens to relativize the findings of sociology by suggesting that they are not discoveries but instead merely ways of looking at the social world. John Shotter, for example, recently discussed the tension between realism and constructionism in Harré's work, noting that social constructionism suggests that since no independent reality exists and social reality can only be understood from 'within', there cannot be any independent standards to which to appeal and hence sociology risks sliding 
into 'relativistic nihilism' (1993: 89). Similarly, Bruno Latour has noted that reflexive sociologists of science find themselves caught in self-contradictory positions 'from which they cannot escape except by indefinite navel-gazing, dangerous solipsism, insanity and probably death' (1988:155). So, the apparently simple sociological claim that what people think about what they do is an important part of that activity, turns out to have important and potentially damaging reflexive implications for sociology itself.

I want to suggest that there are two versions of social constructionism, the first procedural, the second reflexive. The procedural version emphasizes that the ways in which we interpret activities are an important part of those activities, the reflexive version emphasizes that this is an all-embracing argument and hence can be applied to sociology and social constructionism themselves. For advocates of procedural social constructionism, such as Gergen, reflexivity deflects attention away from the processes whereby people make sense of the social world. For advocates of reflexive social constructionism, reflexivity is a revelation about the limits and validity of sociological claims. The project of procedural social constructionists is to explicate the signs, meanings and procedures by which we make sense of the social world, thereby revealing the intricate and subtle aspects of everyday interaction. For supporters of this project, a concern with reflexivity does not expand our understanding of these processes but instead threatens to displace them. Erving Goffman stated this position forcefully in Frame Analysis:

Methodological self-consciousness that is full, immediate, and persistent sets aside all study and analysis except that of the reflexive problem itself, thereby displacing fields of inquiry instead of contributing to them. (1974:12)

By contrast, reflexive social constructionists, such as Woolgar (1988), view their non-reflexive colleagues as unwitting writers of realist fiction. They propose instead to be self-consciously literary so as to be able to use the range of narrative devices available to novelists. Critics of reflexive social constructionism point out that this way of doing sociology 'leads nowhere' and supporters reply that getting nowhere can itself be an accomplishment (see Collins and Yearley, 1992: 305).

The question of the relationship between social constructionism and reflexivity can be understood as a question about how 'fuzzy' sociology ought to be. Reflexive social constructionists are willing, even enthusiastic, to reorder our general knowledge of the social world by eliding the differences between explanation, description, discovery, invention, theory and evidence. The result is a version of sociology that must appeal to 'community standards' (which Rorty thinks of as an appeal to ethnocentrism) to justify their 'findings'. Non-reflexive social constructionists are happy to blur the difference between explanation and description, but they balk at the suggestion that they are inventing the social world rather than discovering its mechanisms or procedures. From their 
perspective, the critical task is to understand the procedures by which people construct and maintain a sense of the social world. Martha Minow states this position very clearly:

I believe we make a mistake when we assume that the categories we use for analysis just exist and simply sort our experiences, perceptions, and problems through them. When we identify one thing as like the others, we are not merely classifying the world; we are investing particular classifications with consequences and positioning ourselves in relation to those meanings. When we identify one thing as unlike the others, we are dividing the world; we use our language to exclude, to distinguish - to discriminate. (1990:3)

Minow develops her argument by discussing a paper by Harold Herzog about the curious moral status of mice in laboratory experiments, in an attempt to persuade us that mice exist for us only in the context of various categories. Our description of these mice is constitutive of their status and will also determine their life chances. A mouse officially engaged in an experiment has statutory rights, and its welfare is monitored by a division of the Department of Agriculture. However, should the mouse escape, either by accident or ingenuity, it is transformed into a 'pest' with no civil rights. Should it fall from the laboratory bench to the floor, it also loses all rights instantly. Finally, should the laboratory have a supply of snakes, then the mouse can at any time become transformed from a sentient being with moral and legal rights into somebody else's lunch (Minow, 1990: 4-5; Herzog, 1988).

The social world, even the precarious social world of laboratory mice, is 'saturated' in meaning to use Kenneth Gergen's (1991) apt expression. We live in, and in a sense we are, a compilation of semiotic systems that channel, exchange and constantly produce negotiated and negotiable meanings. As Goffman (1971) puts it, we are 'sign vehicles'. It is extremely difficult to produce even an approximate description of this process, and even this limited claim does not do justice to the indeterminate character of many of these signs and meanings. Nor can they be eliminated from analysis on the grounds that they are merely incidental features of the social setting. Rather, the finely grained details of everyday interaction are constitutive of the interaction itself.

This can be shown by considering Heritage's (1984) analysis of the apparently simple comment: 'Why don't you come and see me sometime?' This can be heard in different ways: it can be taken as a complaint, a request, an invitation, a question and so on. If the speaker emphasized the word 'you', as in 'Why don't you come and see me sometime?', then the utterance can be heard to be distinguishing the recipient from somebody else who may or may not have already responded to this query. The person responding to the utterance is then put in a delicate position, because any reply will be heard as an interpretation of this statement, and as such it commits the respondent to one (and possibly an 
unintended) version of it. To miss these subtle differences is to miss the constitutive elements of the interaction.

Goffman's work offers a sustained and compelling account of these intricate procedures as they unfold in face-to-face interaction. Even though Goffman understood the reflexive possibilities available to sociologists, and even though he could on occasion use them brilliantly, as in the preface to Frame Analysis, he typically avoided reflexivity for fear of reducing his analysis to the question of reflexivity itself. Some of his critics, however, have pointed out that his work can nevertheless be read reflexively, a reading that transforms his findings from discoveries about the social world to inventions or reinventions of it, created by the imposition of a vocabulary on to their subject-matter. Reflexive readings suggest that the examples Goffman gives seem to tell us about the usefulness of a schema rather than about an element of the social world. The literary critic Fredric Jameson stated this position in a review of Frame Analysis:

... it is hard to escape the impression that logical priorities have been reversed ... and ... the various examples and illustrations [are] useful merely to show how wide the range of applicability of [his analysis]; and, as in a dictionary or grammar book, to furnish a range of different but acceptable syntactical exercises for the beginner to practice on. But this means that Frame Analysis is only apparently about social life; in reality, it is self-referential. (1976:128)

Jameson is neither the first nor the last to discuss this problem in Goffman's work. Aaron Cicourel had earlier suggested that all of Goffman's work is 'prematurely coded' (1974:24), that it is a set of schemata that demonstrates its range of application. Clearly this argument runs counter to the prevailing view that Goffman was a master of naturalistic observation and a successor to Simmel. Schegloff suggests that we mistakenly think that Goffman's work is 'densely empirical' because of Goffman's mastery of the 'darting observation' that generates an evocative 'sociology by epitome' (1988: 101).

Anderson and Sharrock (1982) offer a related set of criticisms. They suggest that Goffman's interpretations of face-to-face interaction produce the 'solution before the puzzle', since they precede any serious engagement with empirical data. They claim that Goffman's work begins with the result that it is meant to discover and then develops in what Watson (1992) calls a 'pattern-elaborative' manner, which means that it exploits the reader's willingness to become a 'pattern detector' who can extend the analysis into new settings. This suggestion is very similar to Jameson's observation that Frame Analysis contains 'syntactical exercises for the beginner to practice on'.

This suggests that Goffman is imposing a vocabulary and then 'proving' its usefulness, when what he should have been doing was the close, naturalistic observation of actual social interaction. This criticism has been made by ethnomethodologists, who, following implicitly or explicitly the Wittgenstein of 
the Philosophical Investigations, are principally interested in the ways in which the in situ production of social order generates our sense of living in a regulated and understandable world (Garfinkel, 1984; Maynard and Clayman, 1991). For ethnomethodologists, the way to study these practical activities is through the detailed description of naturally occurring interaction, and this description will produce sociological discoveries about the endogenous order exhibited in mundane interaction. These discoveries identify the sense-making devices through which the social world is routinely and unproblematically made understandable. Devices of this kind reveal the ways in which a hopelessly indexical world is 'remedied' and made intersubjectively understandable to participants.

Ethnomethodologists endeavor to uncover the complicated web of meanings which is activated in everyday interaction through indexical expressions, whose purpose is to express a complicated sentiment in a flexible way. They argue that to understand the social world is to understand the process of remedying indexicals. Michael Lynch (1991) explained this point by recalling an explanation given by Harvey Sacks of the description of someone as a 'fast driver'. Lynch recounts Sacks' argument that:

'You like to drive cars fast' can be preferred over any numerical account of miles per hour read off a speedometer. The standard against which 'fast' is measured is 'the traffic', where 'traffic' is produced in situ by drivers who drive so as to be 'with' the traffic; drivers who, in effect, constitute the very traffic they are 'with'. The expression 'fast' translates into no single numerical formulation, since the measurement device - 'fast $/ \mathrm{slow} /$ ' with traffic' - is flexibly used in reference to the vicissitudes of traffic, local speed limits, and police surveillance. (1991: 92-3)

So, the apparently simple lay description of someone as a 'fast driver' turns out to be an extremely intricate assessment of an approach to driving that does not simply cover speed, as one might suppose, but instead describes speed relative to the range of contingencies that drivers may encounter.

However, ethnomethodologists are themselves divided by the question of reflexivity, since considering its role in their own analysis directs attention away from the detailed description of social life. Some ethnomethodologists therefore suppress questions of reflexivity. This charge will seem odd to many ethnomethodologists, who were very interested in this phenomenon in the prepostmodern 1960s, when reflexivity was not a fashionable issue. However, in recent times, ethnomethodologists have, as shown by Pollner (1991), emphasized 'endogenous reflexivity' over 'referential reflexivity'. The former refers to 'how what members do in, to, and about social reality constitutes social reality'; the latter 'conceives of all analysis - ethnomethodology included - as a constitutive process' (1991:372). In order to focus their efforts on the 
fine-grained description of everyday interaction, ethnomethodologists accentuate the importance of endogenous reflexivity and suppress referential reflexivity. This is because referential reflexivity runs the risk of turning the analysis in upon itself, at the expense of detailed, naturalistic observation. This debate is very familiar to contemporary sociologists of science (see Woolgar, 1988 and Pickering, 1992). The question of whether the risks of referential reflexivity outweigh the gains remains unanswered. Gergen (1985) acknowledges that social constructionism is not immune from reflexive criticisms and hence it cannot offer 'truth through method'; nevertheless he holds on to the idea that a variety of research methods can still produce 'compelling' arguments (1985:272-3). Reflexivity certainly has the role of unsettling inquiries whenever they begin to claim an objectivity or importance that is beyond the competence of any sociological theory; but whether referential reflexivity has a greater role remains to be seen.

In this article I have suggested that the social constructionist perspective can be understood in either procedural or reflexive terms. Each of these options introduces a degree of fuzziness into analysis. Reflexive social constructionists enthusiastically welcome extensive and irremediable fuzziness, happily blurring the distinctions between description and explanation, between discovery and invention, between theory and evidence. Procedural social constructionists allow in more fuzziness, but they suppress fuzziness whenever it threatens to undermine their own findings. By contrast, fuzzy, reflexive social constructionists generate vocabularies which reorder our knowledge of the social world. They acknowledge the limitations of social theory and try to reconcile themselves to their new status, not as physicists or zoologists but as literary critics with empirical ambitions.

Cleveland State University

\section{BIBLIOGRAPHY}

Anderson, R. and Sharrock, W. (1982) 'Sociological Work: Some Procedures Sociologists Use for Organizing Phenomena', Social Analysis 11 (November): 79-93.

Berger, P. and Luckmann, T. (1966) The Social Construction of Reality. Harmondsworth, Mx: Penguin.

Cicourel, A. (1974) Cognitive Sociology. New York: Free Press.

Collins, H. M. and Yearley, S. (1992) 'Epistemological Chicken', in Pickering, 1992:301-26.

Garfinkel, H. (1984) Studies in Ethnomethodology. Cambridge: Polity Press.

Garfinkel, H. (1988) ' Evidence for locally produced, naturally accountable phenomena of order, logic, reason, meaning, method, etc. in and as of the essential quiddity of immortal ordinary society (I of IV): an Announcement of Studies', Sociological Theory 6: 103-9. 
Gergen, K. (1985) 'The Social Constructionist Movement in Modern Psychology', American Psychologist 40: 266-75.

Gergen, K. (1991) The Saturated Self: Dilemmas of Identity in Contemporary Life. New York: Basic Books.

Goffman, E. (1971) Relations in Public. Harmondsworth, Mx: Penguin.

Goffman, E. (1974) Frame Analysis. Boston, MA: Northeastern University Press.

Heritage, J. (1984) Garfinkel and Ethnomethodology. Cambridge: Polity Press.

Herzog, H. (1988) 'The Moral Status of Mice', American Psychologist 43 (June): 473-4.

Jameson, F. (1976) 'Review of Frame Analysis', Theory and Society 13:119-33.

Kitsuse, J. (1962) 'Societal Reactions to Deviant Behavior: Problems of Theory and Method', Social Problems 9:247-56.

Latour, B. (1988) 'The Politics of Explanation: An Alternative', in Woolgar, 1988: 155-76.

Lynch, M. (1991) 'Method: Measurement - Ordinary and Scientific Measurement as Ethnomethodological Phenomena', in G. Button (ed.) Etbnomethodology and the Human Sciences. Cambridge: Cambridge University Press.

Maynard, D. and Clayman, S. (1991) 'The Diversity of Ethnomethodology', Annual Review of Sociology 17:385-418.

Minow, M. (1990) Making All the Difference: Inclusion, Exclusion, and American Law. Ithaca, NY: Cornell University Press.

Pickering, A., ed. (1992) Science as Practice and Culture. Chicago: University of Chicago.

Pollner, M. (1991) 'Left of Ethnomethodology: The Rise and Decline of Radical Reflexivity', American Sociological Review 56: 370-80.

Rorty, R. (1991) Philosophical Papers, Vol. 1. Cambridge: Cambridge University Press.

Schegloff, E. (1988) 'Goffman and the Analysis of Conversation', in P. Drew and A. Wootton (eds) Erving Goffman: Exploring the Interaction Order. Cambridge: Polity Press, 89-135.

Shotter, John (1993) Cultural Politics of Everyday Life. Buckingham: Open University Press.

Watson, R. (1992) 'The Understanding of Language Use in Everyday Life: Is there a Common Ground?', in G. Watson and R. Seiler (eds) Text in Context. Newbury Park, CA: Sage, 1-19.

Woolgar, S., ed. (1988) Knowledge and Reflexivity: New Frontiers in the Sociology of Knowledge. Newbury Park, CA: Sage. 